DOI https://doi.org/10.30525/978-9934-26-008-7.2-14

\title{
PROPOSALS FOR IMPROVING THE QUALITY OF RADAR CONTROL OF AIRSPACE BY USING THE INFORMATION OF THE AUTOMATIC INDEPENDENT COOPERATIVE SURVEILLANCE SYSTEM ADS-B
}

\author{
Fedorov A. V., Pukhovyi O. V.
}

\section{INTRODUCTION}

With the development of aviation and the increase in freight and passenger traffic, the implementation of the tasks of conducting radar control (RC) of the air situation in the inspection area of radar is somewhat complicated. This is due to the presence of a large number of air objects (AO) in the air at the same time.

With such intense air traffic, the air situation becomes more complicated and the requirements for the accuracy of determining the coordinates of the AO increase.

At present, the tasks of airspace control of Ukraine are assigned to air traffic control (ATC) units in their areas of responsibility and units of Radar Troops (RT) of Air Forces (AF) of the Armed Forces of Ukraine involved in the tasks of airspace control of Ukraine.

Currently, RT of the Armed Forces of Ukraine receive the latest models of domestic radars, such as radar MR-1, MR-18, DR-1, 79K6 (80K6M) "Pelican". Full equipping of each of these units with new (upgraded) radars requires significant financial support, additional increase in the cost of creating and maintaining radar area and cannot be done in the medium term. At the same time, there are a large number of two-coordinate survey radars of the "old" fleet such as P-18, P-19 and modernized radars P-18MU, P-18MA with mechanical rotation. These radars are not able to ensure the detection of modern low-visibility AO with the required quality.

Thus, at present, when solving the problem of detecting inconspicuous $\mathrm{AO}$, the discrepancy between the trends of development of $\mathrm{AO}$ and the capabilities of existing radars in terms of quality management of RC has intensified.

New information technologies are widely used to solve this discrepancy in improving the methods of detecting inconspicuous radar AO. 


\section{Analysis of the existing system of radar control of airspace and ways for its improvement}

For the organization of observation of $\mathrm{AO}$ on the routes of movement in the airspace of Ukraine in the ATCU system used 8 track radars "ТРЛК-10" (as part of the primary radar "Skala-M" and secondary radar "Koren-AC"), 3 autonomous secondary radar type "Koren-AC", 5 monopulse radars (MSSR) type IRS-20MP/L and SIR-S.

To monitor air traffic in the areas of aerodromes and in terminal areas, 6 aerodrome-route radars of the ATTC-33S/SIR-S type and 10 aerodrome radars of the АОРЛ-85, ДРЛ-7СМ, radar complex "Irtysh", ASR-22/AL are used".

RT units of the Armed Forces of Ukraine exercise control over the airspace of Ukraine in the course of combat duty in cooperation with air traffic control units (ATCU) and units of the United Civil-Military System (UCMS). The structure of the integrated civil-military air traffic control system of air traffic organization is presented in Figure 1.

Control over the observance of the procedure for the use of the airspace of Ukraine by all $\mathrm{AO}$ is carried out on the basis of radar and dispatch control data ${ }^{2}$.

$\mathrm{RC}$ is the continuous monitoring of AO flights by radars and determining their affiliation by means of state identification. It is carried out in the detection zones of regular radars, as well as additional radars that are included for control and performance of other tasks.

The radar control function is entrusted exclusively to the RT of AF.

Dispatch control is the estimated of determination of the location of $\mathrm{AO}$ on the basis of flight notifications and current flight schedules.

1 Сайт «Аеротехніка». URL: http://www.aerotechnica.ua/ (Last accessed: 13.11.2020).

2 Бакуменко Б.В. Тактика радіотехнічних військ : навчальний посібник. Б.В. Бакуменко, В.І. Боровий, В.В. Ковкін та ін. ; за заг ред. Б.В. Бакуменка. Харків, 2007. 228 с. 


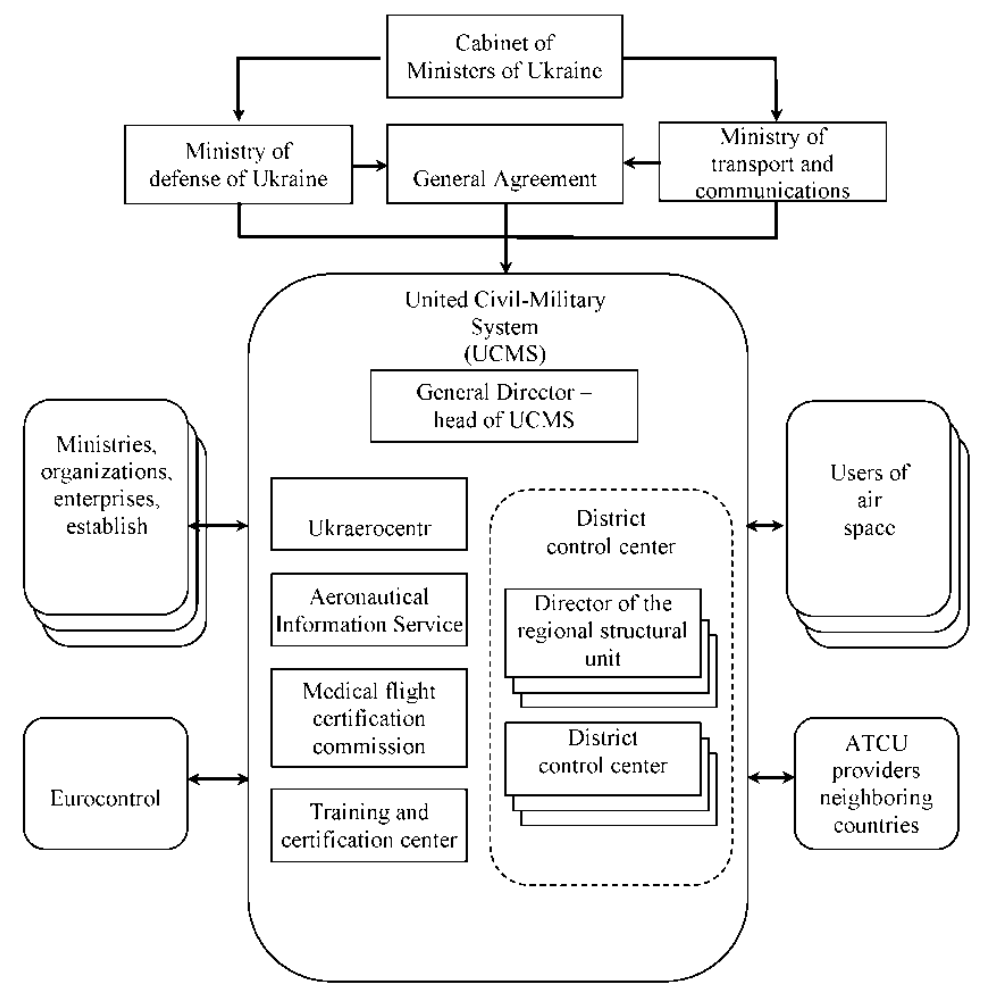

Fig. 1. Structure of the unified civil-military ATC system

The Air Force Armed Forces of Ukraine carry out radar control of the airspace provided within the radar field on duty, which is created at the expense of the RT Air Force of Armed Forces of Ukraine included in the schedule of radar reconnaissance, and dispatching control, the tasks of which are performed at command post of RT units throughout Ukraine.

At present, in modern hybrid wars, when there is a large number of $\mathrm{AO}$ in the airspace, military facilities or AO that violate the state border can mimic of civilian AO (Figure 2). Thus, the inconsistency between the capabilities of existing radar facilities for radar reconnaissance and the requirements for detection and issuance of radar information has now become more acute. One of the methods to increase the efficiency of RC is to use information from disparate sources. 


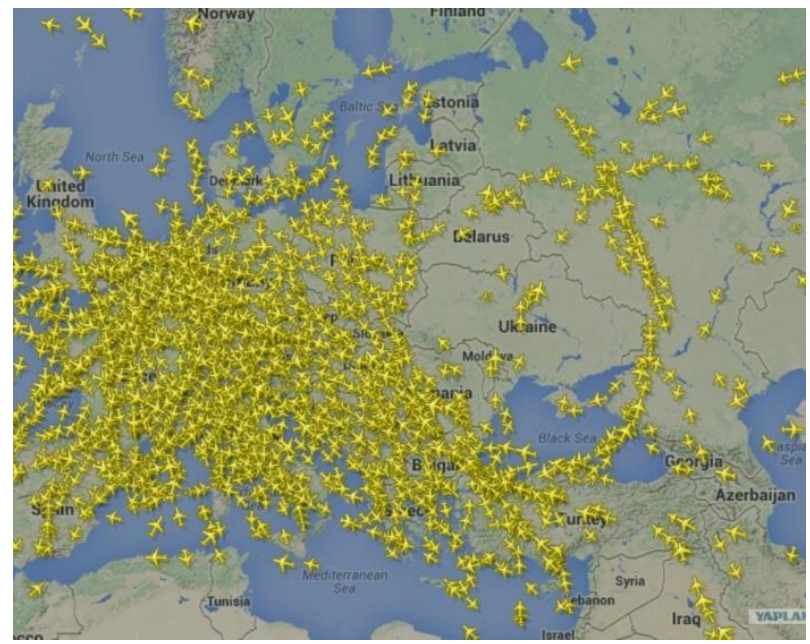

Fig. 2. Air situation along the state border of Ukraine

The airspace RC system must provide the following tasks ${ }^{3}$ :

- continuity of RC;

- providing current information on the air situation in public and military administration in peacetime and wartime;

- timely warning of an air attack;

- ensuring the issuance of radar information with the necessary discretion, the minimum time of delay at military control points to assess the air situation, solving the tasks of targeting and control of troops, firearms, electronic warfare;

- information support of combat operations of all types of aviation;

- ensuring control of the legality and order of use of airspace, identification of $\mathrm{AO}$ that poses a potential threat to the state or other air traffic participants;

- ensuring control over the procedure for crossing the state border;

- ensuring the safety of aviation flights, air traffic control, radar support of flights and flights of aviation, prevention of conflict situations in the air, etc.

3 Лещенко С.П., Колеснік О.М., Бейліс Л.В., Грицаєнко С.А. Шляхи створення єдиної картини повітряної обстановки для виявлення загрозливих $\mathrm{i}$ кризових ситуацій у повітрі. Новітні технології - для захисту повітряного простору : тези допов. 13-ої наук. конф. (Харків, 12-13 квітня 2017 р.). Харків : ХНУПС, 2017. С. 204. 
To solve the tasks, the spatial indicators of the combat capabilities of the RC system must fully ensure the detection and maintenance of AO in the entire range of possible altitudes and speeds of their flight. At the same time, the existing RC system is not able to fully ensure the solution of the tasks assigned when using new types of inconspicuous and smallscale means of air attack (MAA).

The root means square error (RMSE) of determining the coordinates of the AO depends on the tactical and technical characteristics of the radar operating in the responsibility area. However, with the development of MAA, the capabilities of existing radar facilities are somewhat limited. This is due to a number of factors ${ }^{4}$ :

- increase speeds of $\mathrm{AO}$;

- increasing the number of $\mathrm{AO}$ in the airspace;

- reduction of effective scattering area of $\mathrm{AO}$;

- geometrical features of AO construction and application of radio absorbing AO surface.

It is known that the accuracy of determining the coordinates of the AO is determined by the value of the RMSE- $\sigma$. The external and internal factors are influence to accuracy of determining the coordinates of $\mathrm{AO}$.

The internal factors determining the RMSE include:

$\sigma_{i}$ - where $\mathrm{i}=1,2, \ldots \mathrm{n}, \mathrm{RMSE}$ in the $\mathrm{i}$-th node of the radar;

$\sigma_{n}-$ the potential RMSE measuring the range defined by the expression (1).

$$
\sigma_{n}=\frac{\Delta D}{\sqrt{\pi q}}=\frac{c \cdot \tau_{d i}}{2 \sqrt{\pi q}}
$$

where $\tau_{d i}$ - probe pulse delay time;

$q$ - signal-to-noise ratio.

The external factors determining the RMSE include:

$\sigma_{p}-$ RMSE propagation of radio waves related to the conditions of their propagation;

Thus, the total RMSE coordinate determination is determined by expression (2):

$$
\sigma_{R}=\sqrt{\sum_{i=1}^{n} \sigma_{i}^{2}+\sigma_{n}^{2}+\sigma_{p}^{2}}
$$

4 Маляренко А.С. Системи вторинної радіолокації для управління повітряним рухом та державного впізнавання : довідник. Харків, 2007. 78 с. 
According to the tactical and technical characteristics of modern radars, which are in service with the RT AFU, the standard error of determining the coordinates of the AO is in the range from $300 \mathrm{~m}$ to $500 \mathrm{~m}$.

The analysis of the existing trends in the development of radar in the airspace control system showed ${ }^{5}$ that one of the main trends in the development of radar is the combination the advantages of different types of surveillance in the conduct of airspace RC.

One of the options to increase the efficiency of RC is to use information about the air situation from disparate sources at RV control points. This can generally increase the efficiency of solving problems in the airspace control system.

At present, there are already radar systems that detect $\mathrm{AO}$ in the backlight field of external sources of radiation and use the properties of bistatic effective scattering area AO. Transmitters of the system of television and radio broadcasting, cellular communication and others are used as such sources ${ }^{6}$.

However, recently, in the conduct $\mathrm{RC}$ of airspace, navigation cooperative surveillance systems are widely use. One such system is the system of automatic dependent surveillance in radio mode (ADS-B).

In order to increase the efficiency of airspace control, the use of information from the ADS-B dependent cooperative surveillance system is proposed.

The accuracy of determining the coordinates of the AO according to ADS-B is much higher than the accuracy of determining the coordinates of $\mathrm{AO}$ according to the radar and at different dualities can be from $40 \mathrm{~m}$ to $75 \mathrm{~m}$. This is primarily due to the fact that in the ADS-B system, the coordinates of the AO are determined by GPS data on board the AO and as close as possible to the etalon.

This makes it possible to combine information from radar and information about $\mathrm{AO}$ from the ADS-B system.

The resulting RMSE determination of the coordinates of the AO can be calculated by expression (3):

$$
\sigma_{\Sigma}=\sqrt{\frac{\sigma_{R}^{2} \cdot \sigma_{A D S-B}^{2}}{\sigma_{R}^{2}+\sigma_{A D S-B}^{2}}},
$$

5 Web-site "ICAO Uniting Aviation". URL: https://www.icao.int/Pages/ default.aspx (Last accessed: 14.11.2020).

${ }^{6}$ Обод I.І., Черних О.П., Заволодько В.В., Ткаченко О.Ю. Інформаційна модель систем спостереження повітряного простору. Системи обробки інформаціï. 2016. Вип. 5 (142). С. 35-37. 
де $\sigma_{R}^{2}$ - RMSE determination of AO coordinates according to radar data; $\sigma_{A D S-B}^{2}-$ RMSE determination of AO coordinates according to ADS-B.

Thus, according to information which are given from additional source (data from the ADS-B system), the RMSE coordinate determination can be reduced by approximately $35-40 \%$.

The ADS-B system is an additional form of electronic surveillance used to provide air traffic services on routes and in aerodrome areas ${ }^{7}$.

In fact, the ADS-B is an element of the mode " $\mathrm{S}$ " of the secondary surveillance radar system for air traffic control RBS (RadarBeaconSystem) ${ }^{8}$.

Automatic Dependent Surveillance (ADS-B) is a cooperative surveillance technology in which $\mathrm{AO}$ determines its location via a satellite navigation system and distributes it to the on-board transponder. This information can be received by both ground stations of ATCU units and other AO, which allows crews to be more situationally aware (Figure 3).

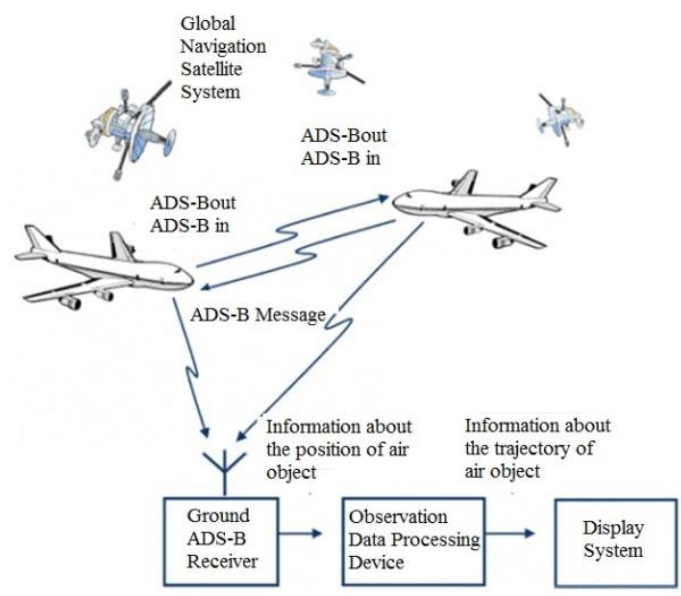

Fig. 3. ADS-B system for surveillance in the interests of air traffic services

\footnotetext{
7 Web-site "ICAO Uniting Aviation". URL: https://www.icao.int/Pages/ default.aspx (Last accessed: 14.11.2020).

8 Лещенко С.П., Колесник О.М., Грицаєнко С.А., Бурковський С.I. Використання інформації ADS-B в інтересах підвищення якості ведення радіолокаційної розвідки повітряного простору. Наука і техніка Повітряних Сил Збройних сил України. 2017. Вип. № 3(28). С. 69-75. DOI: 10.30748/nitps.2017.28.09.
} 
ADS-B - "automatic" - because it operates without the intervention of the crew. "Dependent" - because it depends on the data of the navigation systems of the aircraft.

ADS-B technology, which consists of two different services, "ADS-B Out" and "ADS-B In", may well replace the radar as the main means of monitoring air traffic.

"ADS-B Out" through the on-board transmitter disseminates information on the exact location, altitude and speed of the AO, as well as other data from the on-board systems of the AO.

"ADS-B In" receives information from the FIS-B (Flight Information Service) and TIS-B (Other Traffic Information) channels, as well as other ADS-B data, such as direct communication with an AO nearby.

ADS-B transmits a large amount of data, but to solve the problem of airspace reconnaissance are of interest the following ${ }^{\text {? }}$ :

- coordinates of the AO in the coordinate system WGS-84 (transmitted 2 times per second);

- values of AO height, speed and course;

- value of vertical speed;

- mode code "A" of the RBS system (SQUAWK);

- ICAO address of the AO (transmitted in each message);

- call sign (Callsign) of the AO.

These data are emitted with varying discreteness from 0.5 seconds to 10 seconds.

The coordinates of the AO in the WGS- 84 system are determined by onboard GPS navigators, they have significantly higher accuracy than data from radar. The discreteness of coordinate data transmission ( 2 times per second) is also significantly less than the discreteness of data from radar. Speed and course values are in most cases also taken from onboard GPS navigators, but can be taken from other onboard

${ }^{9}$ Heribert Lafferton, Dr. Roland Mallwitz. Surveillance Transition Scenario for German Airspace. Results of the DFS ADS-B Study Group. DFS Deutsche Flugsicherung GmbH. January 31, 2007.

9. Griffiths H.D. From a Different Perspective: Principles, Practice and Potential of Bistatic Radar. International Conference on Radar. (Adelaide, Australia, 3-5 September 2003). 2003. Pp. 1-7.

13. Standards of USA (2009), "RTCA DO-260B. Minimum Operational Performance Standards for $1090 \mathrm{MHz}$ Extended Squitter Automatic Dependent Surveillance - Broadcast (ADS-B) and Traffic Information Services - Broadcast (TIS-B)", Washington. P. 185. 
equipment. In most cases, the altitude value is taken from the barometric altimeter of the AO.

The AO's ICAO address is a 6-bit 16-year code provided to the AO for its entire existence for use in the "S" mode of the RBS air traffic control system.

Appropriate radio receivers must be used to receive data from $\mathrm{AO}$ in the ADS-B system. Preliminary analysis shows that such receivers are not manufactured in Ukraine. Production of receivers takes place in the European Union, Russia and China. All ADS-B radios can be divided into three categories ${ }^{10}$ :

- professional radio receivers of the ADS-B system are intended for use by ATCU;

- specialized radio receivers of the ADS-B system, intended for use by both ATCU and private users;

- frequency radio scanners are intended for use by private users.

Professional radio receivers of the ADS-B system are completed with regular external antenna devices and carry out full processing of the received signals of the ADS-B system ${ }^{11}$.

Specialized radio receivers of the ADS-B system are equipped with an external antenna, are made in a sealed corps, which allows them to be placed on the street and raised on masts. The receiver performs minimal processing of received signals.

When using ADS-B data in radio engineering departments, they, in contrast to the ATCU, are additional means. The presence of an AO detected by ADS-B should be confirmed only if it is detected by some radar. The identification is performed when the AO mark from the ADS-B and the radar hits one multidimensional strobe. The dimensions of the strobe are the differences in space, speed, course and height (the latter only for three-coordinate radars). When receiving radar data from a track radar, the SQUAWK code of OA must by the same. When the conditions of identification are met, the data from the ADS-B (AO type,

10 Федоров А.В., Чалий В.В., Фінаєв В.П. Використання системи мультилатерації для підвищення якості радіолокаційного контролю повітряного простору. Системи управління, навігаџї та зв 'язку. 2018. № 4 (50). DOI: 10.26906/SUNZ.2018.3.055.

11 Лещенко С.П., Колесник О.М., Грицаєнко С.А., Бурковський С.I. Використання інформації ADS-B в інтересах підвищення якості ведення радіолокаційної розвідки повітряного простору. Наука $і$ техніка Повітряних Сил Збройних сил України. 2017. Вип. № 3(28). С. 69-75. DOI: 10.30748/nitps.2017.28.09. 
registration number, AO owner, AO call sign, in some cases flight number and departure and arrival airports) are automatically linked to the $\mathrm{AO}$, which is accompanied by the radar. When accompanying such AO, it is advisable to take the coordinate parameters from ADS-B (AO position, altitude, speed and course) which are much more accurate than the values of these parameters from the radar. In the case that the AO is out of range of the ADS-B receiver, there is an automatic transition to tracking according to the radar data with the preservation of noncoordinated ADS-B data.

The availability of ADS-B data allows to obtain additional information about $\mathrm{AO}$ and increase the accuracy of their tracking. A significant advantage is that these data can be obtained for AO that are not part of the airspace of Ukraine and, accordingly, about which there is no information in the ATCU of Ukraine. That is, it is possible to obtain data on AO that flies along the border of Ukraine without crossing it.

Obviously, the most "interesting" AO for the radio troops will not work in ADS-B. But with such information from other AO (which make up $99 \%$ of airspace users), the allocation of such "interesting" $\mathrm{AO}$ against others is greatly simplified.

Obtaining ADS-B data directly on anti-aircraft missile systems, especially in their autonomous operation, can significantly increase the safety of combat firing.

\section{Features and limitations on the use of information according to the ADS-B system}

It is known ${ }^{12}$ that the data coming from ADS-B receivers should be treated with some confidence because technically the enemy can deliberately distort this data. Although the distortion of these data is prohibited, but when organizing provocative actions, the enemy may knowingly commit such violations. For example, you can make a radio

12 Лещенко С.П., Колесник О.М., Грицаєнко С.А., Бурковський С.I. Використання інформації ADS-B в інтересах підвищення якості ведення радіолокаційної розвідки повітряного простору. Наука $i$ техніка Повітряних Сил Збройних сил Украӥни. 2017. Вип. № 3(28). С. 69-75. DOI: 10.30748/nitps.2017.28.09.

Standards of USA (2009), "RTCA DO-260B. Minimum Operational Performance Standards for $1090 \mathrm{MHz}$ Extended Squitter Automatic Dependent Surveillance - Broadcast (ADS-B) and Traffic Information Services - Broadcast (TIS-B)", Washington. P. 185. 
transmitting device that will emit signals from non-existent targets. The presence of such "virtual" AO can be detected by comparing ADS-B data with data obtained from radar. Even more effective is the use of MLAT technology, which allows you to determine the coordinates of the location of such a transmitter. Another way to distort may be to substitute coordinates in ADS-B messages. Moreover, such distortions may come from law-abiding airspace users. For example, if the satellite navigation system of the AO put the appropriate obstacles. Detection of such distortions is also carried out by comparison with radar data or the use of MLAT technology. The most unpleasant may be the substitution in the messages of the ICAO address of the AO. That is, for example, a reconnaissance $\mathrm{AO}$ emits information that is simulated under a real existing Boeing-737 passenger aircraft, the data of which are present in the database. It is not possible to detect such substitution by comparison with radar data or the use of MLAT technology. The decision to surrender to identify such a situation can be made in several ways. First, it is necessary to constantly receive data on scheduled flights from the ATCU authorities and check this information with current data on the air situation. Unfortunately, ATCU authorities can only provide information on AO that fly or plan to fly only within the airspace of Ukraine. Secondly, it is possible that the AO under which the "mimicry" is carried out is currently flying. Then, at different points in the airspace will be observed two or more AO with the same ICAO number. The presence of such a situation indicates the fact of substitution. Thirdly. Law-abiding $\mathrm{AO}$ uses ADS-B throughout the flight. The offending AO will use the replacement only in some areas of the flight. Thus, a law-abiding AO performing a flight will be detected at the maximum detection range of the receiver for the flight altitude of the AO. Accordingly, if an AO is detected in the ADS-B system within the range of the receiver at high altitude (the AO does not take off from the aerodrome), it may not directly indicate a possible distortion of ADS-B data.

It should be noted that not all, even modern aircraft, are equipped with ADS-B transmitters. For example, most Embraer aircraft are not equipped with such transmitters. Also, not equipped with McDonnelldouglas MD-83 aircraft used by one of the Ukrainian airlines. Most Soviet-made aircraft do not have such equipment. But now almost all aircraft have the ability to work in " $\mathrm{S}$ " mode of the secondary location system RBS. In the secondary location mode, the AO respond to the request signals of the ATCU route locators. The response is performed at the same frequency as the ADS-B, namely $1090 \mathrm{MHz}$. Accordingly, the 
ADS-B receiver is able to receive signals from $\mathrm{AO}$ responses to requests for route locators. And since AO almost always fly in the field of route locators, there are almost always signals of responses. By analyzing these signals, you can get the same data as from ADS-B, except for the current coordinates. Information about the ICAO address is present in the sweater $\mathrm{DF}=11$, information about the height in the sweaters $\mathrm{DF}=4$ and $\mathrm{DF}=20$, information about the SQUAWK in $\mathrm{DF}=5$ and $\mathrm{DF}=21$. Information about the call sign in $\mathrm{DF}=20$ and $\mathrm{DF}=21^{13}$.

In the conditions of RT, the task can be some simplified ${ }^{14}$. When organizing interaction with ATCU and receiving from them radar information from secondary locators operating in modes " $\mathrm{A}$ " and " $\mathrm{C}$ " RBS, there is information about the current coordinates of $\mathrm{AO}$, their altitude and the SQUAWK code. According to the rules of flight in the area of the route locator SQUAWK codes should not be repeated (except for special 2000, 7000, 7500, 7600, 7700). Thus, the SQUAWK code can be used to identify AO coordinates from the secondary locator and "S" RBS mode data from the ADS-B receiver.

Experimental studies have shown that almost $99 \%$ of the AO present in the airspace are either civil commercial AO or privately-owned AO. Most of them are equipped with ADS-B transponders and almost all of them operate in the "S" mode of the RBS system. That is, for most of these AO using ADS-B receivers can set not only their parameters but also the current position, and almost all such AO can establish their presence in the airspace. Combat AO of the CIS countries are not equipped not only with ADS-B transponders, but also with RBS transmitters. That is, for ADS-B receivers, these AO do not seem to exist. Another thing is about non-combat military AO, primarily transport. Virtually all transport AO operating outside their home countries operate in the "S" mode of the RBS system, and some of them are equipped with ADS-B transmitters. In Western countries, almost all military aircraft, including combat, operate in " $\mathrm{S}$ " mode of the RBS system. That is, their presence in the airspace can be detected using

${ }^{13}$ Heribert Lafferton, Dr. Roland Mallwitz. Surveillance Transition Scenario for German Airspace. Results of the DFS ADS-B Study Group. DFS Deutsche Flugsicherung GmbH. January 31, 2007.

14 Лещенко С.П., Колесник О.М., Грицаєнко С.А., Бурковський С.I. Використання інформації ADS-B в інтересах підвищення якості ведення радіолокаційної розвідки повітряного простору. Наука і техніка Повітряних Сил Збройних сил Украӥни. 2017. Вип. № 3(28). С. 69-75. DOI: 10.30748/nitps.2017.28.09. 
ADS-B receivers, and using the data of route locators or MLAT technology, their current position can be detected.

It is known ${ }^{15}$, that the basis of information support for consumers of information of the airspace control system are surveillance systems, which are combined into an information network. Effective use of information on the air situation from disparate sources at RT control points can generally increase the efficiency of solving problems in the airspace control system.

Analysis of the ADS-B system showed ${ }^{16}$ that the data from the ADS-B transponders can be used not only in the interests of conducting $\mathrm{RC}$ of airspace, but also in preparing the radar for operation during autonomous operation. The ADS-B data can be used as reference measurements when conducting tests of radar facilities, in particular when assessing the accuracy of coordinate measurement, as well as to check and adjust their adjustment. The latter is especially relevant for mobile radar, which often changes its position.

It is known ${ }^{17}$ that when deploying the radar after arrival in a given area, it is necessary to carry out topography and adjustment of the station. Currently, there are several ways to align the radar, but the adjustment of the radar using data from the ADS-B system has not received much attention.

In addition, there are situations when the AO does not transmit its coordinates. In this case, to determine the coordinates of AO, you can use

15 Технические положения, касающиеся услуг режима $\mathrm{S}$ и расширенного сквиттера. Международная организаџия гражданской авиаџии. 2012. 352 с.

Вишневський С.Д., Бейліс Л.В. Погляди на розвиток радіотехнічних військ Повітряних Сил Збройних сил України. Новітні технологї - для захисту повітряного простору : тези допов. 11-ої наук. конф. Харк. ун-ту Повітряних Сил ім. Івана Кожедуба (Харків, 8-9 квітня 2015). Харків : ХУПС, 2015. С. 15.

Standards of USA (2009), "RTCA DO-260B. Minimum Operational Performance Standards for $1090 \mathrm{MHz}$ Extended Squitter Automatic Dependent Surveillance - Broadcast (ADS-B) and Traffic Information Services - Broadcast (TIS-B)", Washington. P. 185.

16 Федоров А.В., Худов Г.В., Сова О.В. Метод юстування радіолокаційної станції радіотехнічних військ 3 використанням технології автоматичного залежного спостереження. Системи управління, навігаџіï та зв'язку. 2019. № 2 (54). C. 155-158. DOI:10.26906/SUNZ.2019.2.155.

17 Standards of USA (2009), "RTCA DO-260B. Minimum Operational Performance Standards for $1090 \mathrm{MHz}$ Extended Squitter Automatic Dependent Surveillance - Broadcast (ADS-B) and Traffic Information Services - Broadcast (TIS-B)", Washington. P. 185. 
MLAT technology. MLAT technology is a system of independent cooperative surveillance. The operation of such a system is based on the difference-range multi-position method of detecting the coordinates of AO. To determine the coordinates of the AO using MLAT technology, it is necessary to process signals from at least three receivers with spatial spacing and accurate time synchronization. Using data from ADS-B, it is possible to provide better synchronization of system receivers ${ }^{18}$. Accurate synchronization can be ensured by using ADS-B receivers at spaced positions. Accurate time recording (up to $50 \mathrm{~ns}$ ) can be done using GPS.

MLAT technology is used by the well-known Internet resource "FlightRadar" ", which processes signals from thousands of ADS-B receivers.

When conducting radar control of airspace, provided the combined use of MLAT technology and existing radar facilities, the task can be somewhat simplified.

\section{CONCLUSIONS}

1. Problems of radar control of airspace in the area of responsibility of radio engineering units can be solved using the methods of activepassive radar. In particular, the use of modern technologies and positioning systems. When combining existing radar and information from additional sources, which can be considered the ADS-B system, it is necessary that the system meets the general needs, such as increased accuracy, low cost, high noise immunity, all-weather.

2. One of the possible ways to improve the accuracy of determining the coordinates of the $\mathrm{AO}$ and, as a consequence, improve the quality of $\mathrm{RC}$ is to use a system of dependent cooperative monitoring as an additional source of information about AO.

3. It is shown that the development of methods to increase the accuracy of determining the coordinates of $\mathrm{AO}$ and conducting radar control with the common use of existing radar and information from dependent cooperative surveillance systems (ADS-B) is poorly studied.

18 Федоров А.В., Худов Г.В., Бакуменко Б.В., Тахьян К.А., Ковалевський С.М. Метод синхронізації системи приймачів ADS-B у разі ведення радіолокаційного контролю повітряної обстановки з використанням технології MLAT. Системи управління, навігащії та зв'язку. 2019. № 4 (56). С. 9-12. DOI: 10.26906/SUNZ.2019.4.008.

19 Web-site "Flightradar24". URL: www.flightradar24.com. (Last accessed: 14.11.2020). 
4. The possibility of using the data of the ADS-B system is shown not only in the interests of improving the quality of the radar, but also for checking, correction and adjusting the radar.

5. Currently, the discrepancy between the capabilities of existing radar facilities for conducting RC and the requirements for detection and issuance of radar information has intensified. One of the methods to increase the efficiency of $\mathrm{RC}$ is to use information from disparate sources.

\section{SUMMARY}

The subject of the article is the ADS-B system and its interaction with existing radar facilities during radar control of airspace. The aim is to analyze the possibilities of using the ADS-B system to increase the efficiency of radar control of airspace. Tasks: analysis of known organizational and technical ways to increase the efficiency of radar control of air objects, determining the directions of combining the capabilities of the ADS-B system and information from existing radar, analysis of the possibility of obtaining information from the ADS-B system in radio departments, analysis of features and limitations use of information from the ADS-B system. The following results were obtained. It is established that the ADS-B system is a system of dependent cooperative surveillance, there are several options for solving the problem of identifying potentially dangerous air objects that wants to go unnoticed, or perform "mimicry". The scientific novelty of the obtained results are as follows: improving the quality of radar control of airspace by combining the capabilities of the ADS-B system and information from existing radar facilities.

\section{REFERENCES}

1. Сайт “Аеротехніка”. URL: http://www.aerotechnica.ua/ (Last accessed: 13.11.2020).

2. Бакуменко Б.В. Тактика радіотехнічних військ : навчальний посібник. / Б.В. Бакуменко, В.І. Боровий, В.В. Ковкін та ін. ; за заг ред. Б.В. Бакуменка. Харків, 2007. 228 с.

3. Лещенко С.П., Колеснік О.М., Бейліс Л.В., Грицаєнко С.А. Шляхи створення єдиної картини повітряної обстановки для виявлення загрозливих і кризових ситуацій у повітрі. Новітні технології - для захисту повітряного простору : тези допов. 13-ої 
наук. конф. (Харків, 12-13 квітня 2017 р.). Харків : ХНУПС, 2017. C. 204.

4. Маляренко А.С. Системи вторинної радіолокації для управління повітряним рухом та державного впізнавання : довідник. Харків, 2007. 78 с.

5. Web-site "ICAO Uniting Aviation". URL: https://www.icao.int/Pages/default.aspx (Last accessed: 14.11.2020).

6. Обод I.I., Черних О.П., Заволодько В.В., Ткаченко О.Ю. Інформаційна модель систем спостереження повітряного простору. Системи обробки інформаиії. 2016. Вип. 5 (142). С. 35-37.

7. Лещенко С.П., Колесник О.М., Грицаєнко С.А., Бурковський C.I. Використання інформації ADS-B в інтересах підвищення якості ведення радіолокаційної розвідки повітряного простору. Наука і техніка Повітряних Сил Збройних сил України. 2017. Вип. № 3(28). С. 69-75. DOI: 10.30748/nitps.2017.28.09.

8. Heribert Lafferton, Dr. Roland Mallwitz. Surveillance Transition Scenario for German Airspace. Results of the DFS ADS-B Study Group. DFS Deutsche Flugsicherung GmbH. January 31, 2007.

9. Griffiths H.D. From a Different Perspective: Principles, Practice and Potential of Bistatic Radar. International Conference on Radar. (Adelaide, Australia, 3-5 September 2003). 2003. Pp. 1-7.

10. Федоров А.В., Чалий В.В., Фінаєв В.П. Використання системи мультилатерації для підвищення якості радіолокаційного контролю повітряного простору. Системи управління, навігащії та зв'язку. 2018. № 4 (50). DOI: 10.26906/SUNZ.2018.3.055.

11. Технические положения, касающиеся услуг режима $\mathrm{S}$ и расширенного сквиттера. Международная организащиия гражданской авиации. 2012. 352 с.

12. Вишневський С.Д., Бейліс Л.В. Погляди на розвиток радіотехнічних військ Повітряних Сил Збройних сил України. Новітні технології - для захисту повітряного простору : тези допов. 11-ої наук. конф. Харк. ун-ту Повітряних Сил ім. Івана Кожедуба (Харків, 8-9 квітня 2015). Харків : ХУПС, 2015. С. 15.

13. Standards of USA (2009), "RTCA DO-260B. Minimum Operational Performance Standards for $1090 \mathrm{MHz}$ Extended Squitter Automatic Dependent Surveillance - Broadcast (ADS-B) and Traffic Information Services - Broadcast (TIS-B)", Washington. P. 185.

14. Федоров А.В., Худов Г.В., Сова О.В. Метод юстування радіолокаційної станції радіотехнічних військ 3 використанням технології автоматичного залежного спостереження. Системи 
управління, навігаиії та зв'язку. 2019. № 2 (54). С. 155-158. DOI: 10.26906/SUNZ.2019.2.155.

15. Федоров А.В., Худов Г.В., Бакуменко Б.В., Тахьян К.А., Ковалевський С.М. Метод синхронізації системи приймачів ADS-B у разі ведення радіолокаційного контролю повітряної обстановки 3 використанням технології MLAT. Системи управління, навігації та зв 'язку. 2019. № 4 (56). C. 9-12. DOI: 10.26906/SUNZ.2019.4.008.

16. Web-site "Flightradar24". URL: www.flightradar24.com. (Last accessed: 14.11.2020).

\section{Information about authors:}

Fedorov A. V.,

Graduate Student at the Department of Tactics of Radio-Technical Troops Ivan Kozhedub Air Force University 77/79, Sumska str., Kharkiv, 61023, Ukraine

Pukhovyi O. V., $\mathrm{PhD}$,

Head of the Department of Radio-Technical and Special Troops National Defense University of Ukraine named after Ivan Cherniakhovskyi 28, Povitroflotsky avenue, Kyiv, 03049, Ukraine 